\title{
An Investigation of the Effectiveness of Online Text-to-Speech Tools in Improving EFL Teacher Trainees' Pronunciation
}

\author{
Gonca Yangın Ekşi ${ }^{1}$ \& Sabahattin Yeşilçınar ${ }^{1}$ \\ ${ }^{1}$ Department of English Language Teaching, Gazi University, Ankara, Turkey \\ Correspondence: Gonca Yangın Ekşi, Department of English Language Teaching, Gazi University, Ankara, \\ Turkey. E-mail: goncayangin@gmail.com
}

Received: November 15, 2015

doi:10.5539/elt.v9n2p205
Accepted: January 18, 2016 Online Published: January 20, 2016

URL: http://dx.doi.org/10.5539/elt.v9n2p205

\begin{abstract}
Given the limited time for instruction in the classroom, pronunciation often ends up as the most neglected aspect of language teaching. However, in cases when the learner's pronunciation is expected to be good or native-like, as is expected of language teacher trainees, out-of-class self-study options become prominent. This study aimed to investigate the effectiveness of online text-to-speech tools used by EFL teacher trainees when preparing for an oral achievement test. The study was conducted with 43 junior year teacher trainees at a large state university in Turkey. A pre- and post-test experimental design was used. Both qualitative and quantitative data were collected through a questionnaire to explore the trainees' opinions related to pronunciation and their practices to improve this, a post reflection questionnaire for the effectiveness of the procedure, and a speaking rubric to evaluate the oral presentations of the trainees. The results indicate that the trainees perceived a native-like accent as a measure of being a good language teacher. It was also revealed that text-to-speech websites are effective self-study tools in improving trainees' pronunciation.
\end{abstract}

Keywords: pronunciation teaching, teacher training, text-to-speech

\section{Introduction}

Countries need to make reforms in order to become internationally active players, and to sustain economic growth. Investing in education and training language teachers to meet the demands of the $21^{\text {st }}$ century is an important step to this end. National education systems need to meet the demands of globalization, multiculturalism, fast-developing information and communication technologies. Therefore, it would be beneficial to examine the education systems of other countries and pinpoint useful practices and solutions (Yangin, 2015). In order to train language teachers who can use information and communication technologies, useful classroom practices should be shared in the literature. This study attempts to explore the effectiveness of an online application on improving pre-service English language teachers' pronunciation as a self-study tool.

Pronunciation is often regarded as the Cinderella of language instruction. Time constraints on the one hand, and traditionally more valued aspects like structure, vocabulary or skills, and pronunciation on the other hand, often end up as the most neglected aspects of language instruction (Griffiths, 2004; Derwing, 2010; Nakazawa, 2012; Underhill, 2010; Wei, 2006). It was not favoured in the heyday of the Communicative Approach either. Despite the recent trend that favours integrating pronunciation with language skills (Burgess, 1994), research indicates that teachers acknowledge that they hardly spare any time for teaching pronunciation and leave it up to the learners to develop this skill by themselves (Harmer, 2007).

New digital technologies, and the Internet, are increasingly beneficial for educational purposes. Integrating Information and Communication Technology (ICT) tools encourages constructive learning more efficiently than traditional teaching practices (Bester \& Brand, 2013). These new technology-mediated learning activities foster learner autonomy and also serve as great sources of motivation for language learners (Cardozo \& Orta Gonzales, 2012; Sharma \& Barret, 2007). In her study with Spanish BA students, Calvo Benzies (2013) suggests that the participants found the pronunciation activities monotonous (mainly listening and repeating tasks) with almost no songs, games or the use of computer programs and the internet. Melhorn (2005) points out that one of the main problems is the lack of class time to cover all the needs in pronunciation teaching, and she suggests individual pronunciation coaching activities as a solution. Technology mediated learning enables learners to practice and study outside the classroom at their own pace. 
The advances in speech technology have yielded tools to be used in the teaching of pronunciation and intonation. Technology-mediated learning activities might reduce anxiety and make learners feel more comfortable when practicing their own pronunciation and intonation without being made the centre of attention in the classroom (Nakazawa, 2012). In her study about integrating accent reduction software in advanced English language classes, Seferoğlu (2005) suggests that specifically designed software programs contribute a lot by providing learners with exposure and practice opportunities in EFL settings where natural target language input is scarce. Research on the use of ICT tools in improving pronunciation reveal positive attitudes of learners and instructors about technology-mediated instruction (Sullivan \& Czigler, 2002). Though not sufficient alone, technology can be useful in pronunciation instruction when incorporated into the existing curriculum, allowing the learner to study at their own pace without the scrutiny of the teacher (Zhang, 1998).

Given the fact that in English language teaching non-native teachers outnumber (about eighty percent) the native teachers worldwide (Baştuğ, Karakuzu, \& Akdoğan, 2010), pronunciation instruction plays a significant role in teacher education as well. Good pronunciation is regarded as a desirable quality in language teachers and a lack of it can cause criticism and questioning of professional identity (Demirezen, 2005; Vodopija-Krastonovic, 2012). Accent and pronunciation errors in Teaching Practicums make teacher trainees feel humiliated (Faez, 2010). Non-native teacher trainees are required to have native-like proficiency and pronunciation in the target language to improve EFL learners' oral proficiency (Corcoran, 2011). Although the native speaker model is criticised as being utopian, unrealistic and constrictive in terms of English as an international language (Alptekin, 2002), non-native teachers themselves want to attain native-like pronunciation and they strongly deny abandoning native-speaker pronunciation norms (Corcoran, 2011; Coskun, 2011; Doğançay \& Aktuna, 1998). It appears there is a distinction between regular EFL learners in mainstream education and language teacher trainees in terms of their drives for and attitudes to pronunciation learning, as the latter would become a language teacher and thus a model in the classroom. Several studies cite non-native teachers of English as favouring a native accent (Jenkins, 2005; McKay, 2003) over a non-native accent.

\subsection{Phonology and Pronunciation in the Training of the EFL Teacher Trainees}

It would be wise to distinguish here the terms that are often seen as synonymous: phonology and pronunciation. Phonology is "a branch of linguistics which studies the sound systems of languages" (Crystal, 2008). It is the theory of and knowledge about how the sound system of the Target Language (TL) works in terms of segmental and suprasegmental features, whereas pronunciation is the practice and meaningful use of TL phonological features in speaking. This is supported by practising interpreting those phonological features in TL discourse that one hears (Burgess \& Spencer, 2000). In pedagogy, the training of language teachers and learning English as a foreign/second language have distinct approaches to the role of phonology and pronunciation. To be precise, the regular language learner is supposed to practice listening and speaking, and eventually produce phonological features appropriately or intelligibly but $\mathrm{s} / \mathrm{he}$ does not need to label a particular speech sound or identify intonation and stress features of a particular stretch of language. For the regular language learner, learning how to pronounce the sounds of the TL, and obtaining some knowledge about the phonemic script and word stress as shown in a dictionary would be sufficient. However, knowledge of the phonology of the TL is necessary for teachers (Brown, 1992; Jenkins, 1998). As Burgess and Spencer (2000) point out, non-native speakers intending to teach the TL need to learn about the phonology of the TL along with how to pronounce words.

The English language teacher education programme in Turkey requires teacher trainees to take language skills and fundamental English language knowledge courses in their first year. The following three years mostly focus on methodology courses and practicum. However, for those to be more effective, the first year courses should provide a sound basis in terms of pronunciation. Of the first year courses, two courses focus on improving speech: one on the micro-level training and the other on macro-level skills training. The teacher trainees take Listening and Pronunciation course and Oral Communication Skills course to improve their oral proficiency. The Listening and Pronunciation course involves segmental and suprasegmental aspects of English language pronunciation - basic knowledge of phonetics and phonology, the phonetic alphabet, and stress and intonation patterns and the like. The Oral Communication Skills course aims to improve trainees' oral communicative competence by means of communication-oriented speaking tasks as discussions, individual presentations and other interactive tasks; formal and informal language; and informative and persuasive presentations. The trainees are supposed to transfer knowledge and skills from both courses to eventually attain better communicative competence. The widely accepted "intelligibility" criteria might not be an appropriate goal in pronunciation training in foreign language teacher training programmes because the teacher is one of the main sources of input in the EFL classroom. Hence, trying to reach native-speaker approximation is advised for EFL teacher trainees as they are going to be models for their future students (Corcoran, 2011; Demirezen, 2005). The Ministry of 
Education in Turkey also defines the role played by the teacher as "a model in pronunciation" as one of the language teacher competencies (p. 64).

\subsection{Purpose}

This article is the result of an attempt to find an effective, user-friendly and motivating tool to help EFL teacher trainees to improve their pronunciation outside the class. Among several resources and materials available for pronunciation teaching, the study specifically focuses on text-to-speech websites (namely, imtranslator, ivona and naturalreader) because it is believed that they can be particularly promising for self-study. The above mentioned websites are user-friendly and deliver speech-to-text technology in different English accents. The teacher trainees were expected to discover their pronunciation and intonation errors themselves and assess how close their pronunciation is to that of a native speaker and improve their own when required. It is believed that the present study will fill a gap in using text-to-speech tools to improve pronunciation because literature review yields studies on text-to-speech synthesis in computational linguistics, speech technologies and computational evaluation of language rather than its use in pedagogy (Marchand \& Damper, 2000; Schröder \& Trouvain, 2003; Mc Graw, Badr \& Glass, 2013)

This study aimed to find out about English language teacher trainees' perceptions and practices in pronunciation learning, and the effectiveness of online text-to-speech tools in terms of improvement in pronunciation and as a learning tool to be used in the long run.

The research questions that guided the study were:

1) What are the opinions of EFL teacher trainees regarding pronunciation learning?

2) What do EFL teacher trainees do to improve their pronunciation through self-study?

3) Do text-to-speech websites help EFL teacher trainees to improve their pronunciation?

4) What are EFL teacher trainees' reflections on the usefulness of text-to-speech websites?

\section{Methodology}

\subsection{Design}

A pre- and post-test quasi-experimental design was used to investigate the effectiveness of online text-to-speech tools in pronunciation. Both qualitative and quantitative data were collected from 43 teacher trainees through a questionnaire to explore their opinions and practices related to pronunciation teaching and learning. A post reflection questionnaire was administered to ascertain the effectiveness of the practice, and a speaking rubric was used to evaluate the oral presentations of the trainees in an oral achievement test.

\subsection{Participants}

The participants in this study were teacher trainees attending their first year of studies at a language teacher education programme at a large state university in Turkey. Two groups attending the Oral Communications Course were chosen due to convenience sampling. Although fifty teacher trainees were enrolled in the course, the number dropped due to a lack of attendance. Hence the number of participants in the study was 43 ( 37 females and 6 males). This gender ratio is common in language teaching departments in Turkey.

\subsection{Data Collection and Analysis}

The first questionnaire aimed to collect data about the teacher trainees' opinions and practices in terms of pronunciation learning. It contained both open-ended and closed-ended questions. The first section consisted of 20 Likert-type statements collected from similar studies (Calvo, 2013; Chongning, 2009) that were adapted to fit the participants of this study. The trainees were also asked to select (tick) from a list of tools, materials and strategies the ones that they used to improve their pronunciation. The final four questions in the questionnaire focused on what they did to check the actual pronunciation of words or expressions. The instructor of the course was consulted as to whether the items in the questionnaire served the purpose of ensuring content validity.

A weighted speaking rubric was developed by the researchers and the instructor of the course to assess the performances of the trainees in oral presentations. The rubric consisted of five subsections (fluency, pronunciation and accent, vocabulary, accuracy, and content) and clear definitions for performance and their weight for each section. The trainees were given argumentative topics about which they could express their opinion. They were supposed to give a persuasive talk for about five minutes. The rubric was used to assess the initial performances of the trainees. The teacher trainees received a training session to use text-to-speech websites and the same rubric was used to assess their second performances after the use of the text-to-speech 
websites for preparation. Three raters graded the participants' performance during their speech to ensure inter-rater reliability. The pre- and post-scores of the trainees were analysed through SPSS 21 statistical analysis program. After ensuring the data met normal distribution requirements, the data was analysed via dependent samples t-test.

After the study took place, the trainees received a final questionnaire to collect their reflections on and opinions regarding the procedure. The questionnaire consisted of ten Likert-type questions and two open-ended questions about the effectiveness of online text-to-speech tools. The results are reported below and are then followed by a discussion and implications.

\section{Results}

The findings of the questionnaires and statistical comparison of the pre and post achievement tests are below.

The first questionnaire aims to explore the opinions and practices of teacher trainees in relation to pronunciation. The trainees were asked to rate 20 statements from 1 to 5 (corresponding, to totally disagree, to totally agree respectively). The mean scores and standard deviations for each item are illustrated below:

Table 1. Teacher trainee opinions and practices about pronunciation.

\begin{tabular}{lll}
\hline Survey Items & Mean & Std. dev \\
\hline 1. It's important for me (as a teacher candidate) to have good English pronunciation. & 4.79 & 0.69 \\
2. Acquiring a native-like accent is a goal that I (as a teacher candidate) should strive for. & 4.30 & 0.95 \\
3. The teacher is a model for pronunciation in the classroom. & 4.87 & 0.65 \\
4. Pronunciation is a measurement of being a good English speaker. & 4.17 & 0.79 \\
5. Pronunciation is a measurement of being a qualified English teacher. & 4.15 & 0.84 \\
6. I am not satisfied with my pronunciation. & 3.13 & 1.23 \\
7. I would really like to have better pronunciation. & 4.56 & 0.85 \\
8. My English pronunciation has improved in recent years. & 4.23 & 0.70 \\
9. I feel that I currently have excellent pronunciation skills. & 2.58 & 0.90 \\
10. I would really feel happy if people complimented me on my pronunciation. & 4.17 & 0.96 \\
11. I do not care much when I make pronunciation mistakes. & 2.30 & 1.02 \\
12. Mispronunciation of sounds can cause misunderstanding. & 4.64 & 0.81 \\
13. Mistakes in stress and intonation can cause misunderstanding. & 4.02 & 1.03 \\
14. English pronunciation is difficult master. & 3.51 & 0.96 \\
15. Pronunciation is generally neglected in classrooms. & 2.74 & 1.11 \\
16. Pronunciation can be practised outside the class for improvement. & 4.15 & 1.08 \\
17. Online sources are the best way to get additional practise to improve pronunciation. & 3.56 & 0.96 \\
18. I have problems expressing myself fluently in English. & 2.71 & 1.07 \\
19. I feel shy when speaking English. & 2.31 & 1.18 \\
20. If I were good at pronunciation, I would be more confident in English. & 4.23 & 1.03 \\
\hline
\end{tabular}

The teacher trainees marked the statements from 1-totally disagree to 5-totally agree. The mean scores for each statement show the strength of their agreement. Statements about the importance of pronunciation in teaching as a profession and in communication, and about their willingness to improve their pronunciation, received the highest scores. Satisfaction with their current level of pronunciation and indifference to making mistakes received the lowest scores. The teacher trainees indicated that pronunciation instruction was not neglected in their training programme. It appears that they did not have many problems with feeling at ease about their fluency. 
Table 2. What the teacher trainees' do to improve their pronunciation

\begin{tabular}{lll}
\hline & $\mathrm{f}$ & $\%$ \\
\hline Singing songs. & 24 & 61.5 \\
Listening to songs. & 31 & 79.5 \\
Doing minimal pair exercises. & 6 & 15.4 \\
Seeing movies. & 36 & 93 \\
Recording yourself. & 7 & 17.4 \\
Listen and repeat. & 26 & 66.6 \\
Looking up phonetic transcriptions in dictionaries. & 27 & 69.2 \\
Reading aloud after recorded English material. & 9 & 23 \\
Expanding knowledge about English phonetics, stress and intonation. & 18 & 46.1 \\
Practising how to pronounce phonetic symbols. & 19 & 48.7 \\
Using websites to improve pronunciation. & 10 & 25.6 \\
Listening to podcasts on the internet. & 14 & 35.9 \\
Other (please indicate): & 2 & 5.1 \\
\hline
\end{tabular}

The teacher trainees were asked to mark an option on a list of what they did to improve their pronunciation outside the class. The most popular options were mainly audio activities, namely watching movies, listening to songs, listen and repeat drills and looking up transcriptions. The teacher trainees also preferred sounding phonemes and expanding their knowledge of English phonetics, stress and intonation. The least preferred options were doing minimal pair activities, recording oneself and reading aloud after recorded material. Online sources were not used much. As to options that were not presented in the list, the teacher trainees stated that they also spoke in English with a roommate or to foreign people to improve their pronunciation.

Table 3. How the teacher trainees' check pronunciation

\begin{tabular}{|c|c|c|c|c|c|c|}
\hline & $\mathbf{F}$ & $\%$ & $\mathbf{F}$ & $\%$ & $\mathbf{F}$ & $\%$ \\
\hline When you encounter a new vocabulary & \multicolumn{2}{|c|}{ Almost always } & \multicolumn{2}{|c|}{ Sometimes } & \multicolumn{2}{|c|}{ Almost never } \\
\hline $\begin{array}{l}\text { item, how often do you check its } \\
\text { pronunciation? }\end{array}$ & 11 & 28.2 & 27 & $69.2 \%$ & 1 & $2.6 \%$ \\
\hline \multirow{2}{*}{$\begin{array}{l}\text { How do you check the pronunciation of } \\
\text { a new vocabulary item? }\end{array}$} & \multicolumn{2}{|c|}{ Printed dictionary } & \multicolumn{2}{|c|}{ Online dictionary } & & \\
\hline & 2 & $5.1 \%$ & 37 & $94.9 \%$ & & \\
\hline \multirow{2}{*}{$\begin{array}{l}\text { Do you check your pronunciation for } \\
\text { the words you believe you already } \\
\text { know? }\end{array}$} & \multicolumn{2}{|c|}{ Almost always } & \multicolumn{2}{|c|}{ Sometimes } & \multicolumn{2}{|c|}{ Almost never } \\
\hline & 3 & $7.7 \%$ & 32 & $82.1 \%$ & 4 & $10.3 \%$ \\
\hline \multirow{2}{*}{$\begin{array}{l}\text { Do you use any websites to practise } \\
\text { pronunciation? Do you use any? If yes, } \\
\text { which ones? }\end{array}$} & Yes & & No & & & \\
\hline & 22 & $56.4 \%$ & 17 & $43.6 \%$ & & \\
\hline
\end{tabular}

The teacher trainees checked the pronunciation of a new vocabulary item $(28.2 \%$ almost always, and $69.2 \%$ sometimes) using an online dictionary $(94.9 \%)$. For the words they were already familiar with, 32 teacher trainees $(82.1 \%)$ said that they sometimes checked pronunciation. As to any websites that they used for pronunciation improvement, nearly half of the participants (43.6\%) indicated that they never did. Those who used such online sources specified them as online dictionaries (Cambridge online dictionary n.15, Oxford online dictionary n.7, Tureng n.3, one look n.1) and news channels (cnbc-e, BBC 2, voanews.com, and Youtube). Only one teacher trainee mentioned a website for language learning purposes (reallifenglish.com). 
Table 4. Teacher trainees' Pre- and Post-test results in oral achievement tests

\begin{tabular}{|c|c|c|c|c|c|c|}
\hline & Mean & $\mathrm{N}$ & $\begin{array}{l}\text { Std. } \\
\text { Deviation }\end{array}$ & Std. Error Mean & Correlation & Sig. \\
\hline Pre Fluency & 13.2302 & 43 & 2.10979 & .32174 & \multirow[t]{2}{*}{.736} & \multirow[t]{2}{*}{.000} \\
\hline Post Fluency & 14.1628 & 43 & 1.77429 & .27058 & & \\
\hline Pre Pronunciation & 12.4209 & 43 & 1.82072 & .27766 & \multirow[t]{2}{*}{.695} & \multirow[t]{2}{*}{.000} \\
\hline Post Pronunciation & 13.4977 & 43 & 2.10266 & .32065 & & \\
\hline Pre Total & 68.9767 & 43 & 7.31108 & 1.11493 & \multirow[t]{2}{*}{.764} & \multirow[t]{2}{*}{.000} \\
\hline Post Total & 72.2326 & 43 & 8.03515 & 1.22535 & & \\
\hline
\end{tabular}

\section{Paired Samples Test}

\begin{tabular}{|c|c|c|c|c|c|c|c|c|}
\hline & \multicolumn{5}{|c|}{ Paired Differences } & & \multirow[b]{3}{*}{$\mathrm{df}$} & \multirow{3}{*}{$\begin{array}{l}\text { Sig. } \\
\text { (2-tailed) }\end{array}$} \\
\hline & \multirow[b]{2}{*}{ Mean } & \multirow{2}{*}{$\begin{array}{l}\text { Std. } \\
\text { Deviation }\end{array}$} & \multirow{2}{*}{$\begin{array}{l}\text { Std. Error } \\
\text { Mean }\end{array}$} & $\begin{array}{l}95 \% \\
\text { Interval } \\
\text { Difference }\end{array}$ & $\begin{array}{l}\text { Confidence } \\
\text { of the }\end{array}$ & \multirow[b]{2}{*}{$\mathrm{t}$} & & \\
\hline & & & & Lower & Upper & & & \\
\hline Pre Fluency & -.93256 & 1.44580 & .22048 & -1.37751 & -.48761 & -4.230 & \multirow[t]{2}{*}{42} & \multirow[t]{2}{*}{.000} \\
\hline Post Fluency & & & & & & & & \\
\hline Pre Pronunciation & \multirow[t]{2}{*}{-1.07674} & \multirow[t]{2}{*}{1.55439} & \multirow[t]{2}{*}{.23704} & \multirow[t]{2}{*}{-1.55511} & \multirow[t]{2}{*}{-.59838} & \multirow[t]{2}{*}{-4.542} & \multirow[t]{2}{*}{42} & \multirow[t]{2}{*}{.000} \\
\hline Post Pronunciation & & & & & & & & \\
\hline Pre Total & \multirow[t]{2}{*}{-3.25581} & \multirow[t]{2}{*}{5.30989} & \multirow[t]{2}{*}{.80975} & \multirow[t]{2}{*}{-4.88996} & \multirow[t]{2}{*}{-1.6216} & \multirow[t]{2}{*}{-4.021} & \multirow[t]{2}{*}{42} & \multirow[t]{2}{*}{.000} \\
\hline Post Total & & & & & & & & \\
\hline
\end{tabular}

The pre- and post- test scores in oral achievement tests show that there is a significant difference in pronunciation and fluency subsections of the tests as well as in the total scores at the .05 level. The mean scores in pronunciation, fluency and total grades favoured the post-test performances.

Table 5. Reflections on the teacher trainees' use of text-to-speech websites

\begin{tabular}{lll}
\hline Survey Items & Mean & Std. dev \\
\hline 1. In general the Text-to-Speech (TTS) program is good. & 4.02 & 0.92 \\
2. The pronunciation TTS program is very easy to use. & 4.15 & 0.82 \\
3. Using TTS helps me to depend on myself in learning. & 3.84 & 1.16 \\
4. Using TTS was interesting and useful. & 4.20 & 0.94 \\
5. TTS is effective in improving stress and intonation patterns. & 3.88 & 1.00 \\
6. TTS is effective in learning features of phonemes. & 3.97 & 0.97 \\
7. TTS is effective in practising flow of speech. & 4.06 & 0.98 \\
8. The feedback provided by the TTS program is useful. & 3.72 & 0.94 \\
9. That is the first time I have used this program. & 4.11 & 1.44 \\
10. I would like to use the TTS program again in the future. & 4.20 & 1.05 \\
\hline
\end{tabular}


The teacher trainees found text-to-speech websites user-friendly and useful in improving their pronunciation on their own. Although it was the first time most of the teacher trainees used these, they showed a strong intent to use it in the future again.

Table 6. Pros and cons of text-to-speech websites

\begin{tabular}{ll}
\hline Pros & Cons \\
\hline User-friendly. & Limitations for longer texts. \\
Effective in pronunciation improvement. & Sometimes sounded mechanic/ no emotions. \\
Comparing my own pronunciation with ideal ones. & Low internet speed causes problems. \\
Accents available. & \\
Useful to improve basic intonation. & \\
Effective for word stress. & \\
Listening to longer texts than single words.
\end{tabular}

When asked what they particularly liked or their suggestions for improvement of the websites, the majority of the teacher trainees found them beneficial. Their answers to the open-ended questions revealed that these sites were particularly useful in improving pronunciation, word stress and basic intonation patterns. They also liked the possibility of listening to longer texts that they had generated. One teacher trainee stated that she preferred to check the pronunciation of individual words, whereas 27 teacher trainees said that there was nothing they disliked about it. As to limitations, the teacher trainees suggested that it would be better if they could upload longer texts to listen to. The fact that the utterances sounded mechanic with no emotions received some criticism. Finally, a slow internet connection appeared to cause problems in effective listening.

\section{Discussion}

The findings are discussed below with respect to research questions:

Research Question 1: What are the opinions of EFL teacher trainees regarding pronunciation learning?

As Table 1 illustrates, the teacher trainees strongly believed that a good English pronunciation and a native-like accent was important for them to be good teachers, and they believed that they would be models for pronunciation in the classroom (items 1,2,3,5). This finding is in line with previous research that a good pronunciation is significant in developing professional identity (Demirezen, 2005; Jenkin, 2005; McKay, 2003; Vodopija-Krastonovic, 2012). The trainees showed a clear favour of a native-like accent as a measurement for a good language teacher like their counterparts in similar studies (Corcoran, 2011; Coskun, 2011; Doğançay \& Aktuna, 1998). The teacher trainees believed that their pronunciation had improved in recent years (item 8), and, unlike many mainstream language courses, pronunciation was not neglected in their training programme (item 15), probably because of the Listening and Pronunciation course they had taken the previous term. Still, they were not satisfied enough (item 9) and would have liked to have much better pronunciation (item 7). The teacher trainees expressed discontent over making pronunciation mistakes (item 11). As to the importance of the segmental and suprasegmental aspects of English pronunciation, they were aware that mistakes could cause misunderstandings (items 12, 13). It appears that the teacher trainees found English pronunciation somewhat difficult to master (item 14). For self-study options, the teacher trainees strongly believed that pronunciation could be practiced and improved outside the class (item 16), and viewed online sources as beneficial to this end (item 17). Although they did not express much trouble in fluency, and experienced ease in speaking English, they clearly expressed that they would be a lot more confident if they had better pronunciation.

Research Question 2: What do EFL teacher trainees do to improve their pronunciation through self-study?

With respect to the self-study practices of teacher trainees, Table 2 shows that they mainly preferred to use audio or audio visual material such as songs and movies. The trainees also seemed to be able to transfer their knowledge from the Listening and Phonology course as many referred to transcriptions and knowledge of phonology to improve their pronunciation. A significant finding of the study is that the teacher trainees did not use online sources much despite the availability of several web sources.

It is also worth noting the trainees' responses about how they checked the pronunciation of new words. Nearly all of the trainees used online dictionaries as they could easily be downloaded to mobile phones and were thus 
readily available. However, other web resources were not used widely. Only half of the trainees mentioned using online dictionaries and new channels for pronunciation improvement. This study points to a gap in teacher trainees' knowledge about available online sources that they can use for self-study to improve their pronunciation.

Research Question 3: Do text-to-speech websites help EFL teacher trainees to improve their pronunciation?

The 21 st century has become the information age with all of its technological developments and teacher trainees should be able to use new technologies for continuing teacher development. Teacher development, during both pre-service and in-service training, is significant. To train language teachers to maintain continuing professional development, they need to be equipped with tools for self-study. The present study suggests that oral achievement test scores before and after introducing text-to-speech online tools were statistically compared with respect to the trainees' total grade and the scores that they received from the two subsections of the weighted rubric: pronunciation and accent, and fluency. The results show a significant difference in all three dimensions. Fluency, pronunciation and the total scores in the post achievement test were higher. This suggests that text-to-speech websites are effective in self-study to improve pronunciation.

Research Question 4: What are EFL teacher trainees' reflections on the usefulness of text-to-speech websites?

The findings of the reflection questionnaire reveal that text-to-speech websites were found to be user-friendly and effective. Many teacher trainees stated that they would use it in the future, which is a significant finding in that long term autonomous learning habits are much more effective than one-time attempts. Only some teacher trainees pointed to a few drawbacks of using online text-to-speech tools, i.e. word limits, or mechanic sounding articulation, although the majority of the participants said that there was nothing they disliked about it and found it effective in improving pronunciation of sounds, word stress and basic intonation patterns. Unlike online dictionaries that they used often, text-to-speech websites allowed the trainees to listen to longer texts and hear the flow of speech, which they appreciated.

\section{Limitations of the Study and Suggestions for Further Study}

Lastly, without challenging the value of the findings, some limitations should be noted due to the small scale of this study. As the findings here are from a teacher training programme in Turkey; its implications might be of interest to other EFL teacher training institutions. The findings of this case study can be transferred to similar populations; yet for wider generalisations, further studies need to be replicated.

\section{Conclusion}

The present study offers some preliminary results on the use of text-to-speech websites by English language teacher trainees for pronunciation self-study. The literature on text-to-speech tools are mainly on the technical aspect of text and speech synthesis whereas, to the researchers' knowledge, there are no studies on how to use text-to-speech tools for pedagogy. Based on the findings of this study, it can be concluded that theoretical knowledge about English pronunciation and phonology should be accompanied by useful web-based resources that the trainees can utilise for self-study. Those tools that are perceived as user-friendly and useful would more likely to be used again in the long run, which would eventually yield better learning outcomes. When it comes to pronunciation development, text-to-speech websites are not the only or the best resource available, yet among the many resources available, this study revealed their pedagogical potential for self-study. Therefore, it might be suggested that language teacher trainees should be better informed regarding similar online tools.

\section{References}

Alptekin, C. (2002). Towards intercultural communicative competence. ELT Journal, 56(1), 7-64. http://dx.doi.org/10.1093/elt/56.1.57

Baştuğ, H., Karakuzu, M., \& Akdoğan, M. (2010). Effectiveness of teaching English in a foreign country by a non-native speaker English teacher (NNEST) 2nd International Symposium on Sustainable Development, June 8-9, 2010 Sarajevo.

Bester, G., \& Brand, L. (2013). The effect of technology on learner attention and achievement in the classroom. South African Journal of Education, 33(2), 1-15. http://dx.doi.org/10.15700/saje.v33n2a405

Brown, A. (1992). Twenty questions. In A Brown (Ed.), Approaches to Pronunciation Teaching. Review of English Language Teaching. London: Macmillan.

Burgess, J. (1994). Ideational frameworks in integrated language learning. System, 22(3), 309-318. http://dx.doi.org/10.1016/0346-251X(94)90017-5 
Burgess, J., \& Spencer, S. (2000). Phonology and pronunciation in integrated language teaching and teacher education. System, 28, 191-215. http://dx.doi.org/10.1016/S0346-251X(00)00007-5

Calvo, B. Y. J. (2013). Spanish EFL university students' views on the teaching of pronunciation: A survey-based study. University of Reading. Language Studies Working Papers. In C Ciarlo, \& D S Giannoni (Eds).

Cardozo, A. C., \& Orta, G. M. D. (2012). Technology-mediated activities as a boost to motivation and autonomy in the pronunciation class. In L. Anglada, \& D. L. Banegas (Eds.), Views on motivation and autonomy in ELT selected papers from the XXXVII FAAPI conference.

Chongning, X. (2009). Students' feedback to their pronunciation learning. Teaching English in China CELEA Journal, 32(5), 38-49.

Corcoran, J. (2011). Power relations in Brazilian English language teaching. International Journal, 5, 1-26.

Crystal, D. (2008). A Dictionary of Linguistics and Phonetics: Sixth Edition. UK: Blackwell Publishing. http://dx.doi.org/10.1002/9781444302776

Coşkun, A. (2011). Future English teachers' attitudes towards EIL pronunciation. Journal of English as an International Language, 6(2), 46-68.

Demirezen, M. (2005). The / $\mathrm{J} /$ and /ow/ contrasts: curing a fossilized pronunciation error of Turkish teacher trainees of the English language. Çankaya University Journal of Arts and Sciences, 3, 1-84.

Derwing, T. M. (2010). Utopian goals for pronunciation teaching. In J. Lewis, \& K. L. Ames, (Eds.), Proceedings of the 1st Pronunciation in Second Language Learning and Teaching Conference. IA: Iowa State University.

Doğancay-Aktuna, S. (1998). The spread of English in Turkey and its current sociolinguistic profile. Journal of Multilingual and Multicultural Development, 19(1), 23-39. http://dx.doi.org/10.1080/01434639808666340

Faez, F. (2010). Linguistic and cultural adaption of internationally educated teacher candidates. Canadian Journal of Education and Administration and Policy, 100. Retrieved from https://umanitoba.ca/publications/cjeap/articles/faez-iet.html

Griffiths, B. (2004). Integrating pronunciation into classroom activities. Teaching English. BBC Council. Retrieved from http://www.teachingenglish.org.uk/articles/integrating-pronunciation-classroomactivities

Harmer, J. (2007). The practice of English language teaching. Essex, England: Pearson Education Limited. $\mathrm{http}: / / \mathrm{dx}$. doi.org/10.1093/elt/ccn029

Jenkins, J. (1998). Which pronunciation norms and models for English as an international language? ELT Journal, 52(2), 119-126. http://dx.doi.org/10.1093/elt/52.2.119

Jenkins, J. (2005). Implementing an international approach to English pronunciation: The role of teacher attitudes and identity. TESOL Quarterly, 39(3), 535-543. http://dx.doi.org/10.2307/3588493

Marchand, Y., \& Damper, R. I. (2000). A multistrategy approach to improving pronunciation by analogy. Computational Linguistics, 26(2), 195-219. http://dx.doi.org/10.1162/089120100561674

McGraw, I, Badr, I., \& Glass, J. R. (2013). Learning lexicons from speech using a pronunciation mixture model. Audio, Speech and Language Processing IEEE Transactions, 21, 357-366. http://dx.doi.org/10.1109/TASL.2012.2226158

McKay, S. (2003). Teaching English as an International Language: The Chilean context. ELT Journal, 57(2), 39-148. http://dx.doi.org/10.1093/elt/57.2.139

Mehlhorn, G. (2005). Learner autonomy and pronunciation coaching. Plenary paper on 27 July at the Phonetics Teaching and Learning Conference, University College London, London.

Ministry of National Education. (2014). English Language Teacher Competences. Retrieved from http://otmg.meb.gov.tr/alan_ingilizce_ortaogretim.html

Nakazawa, K. (2012). The effectiveness of focused attention on pronunciation and intonation training in tertiary Japanese language education on learners' confidence: preliminary report on training workshops and a supplementary computer program. The International Journal of Learning, 18(4), 181-192.

Schröder, M., \& Trouvain, J. (2003). The German text-to-speech synthesis system MARY: a tool for research, development and teaching. International Journal of Speech Technology, 6, 365-377. http://dx.doi.org/10.1023/A:1025708916924 
Sharma, P., \& Barret, B. (2007). Blended learning: Using technology in and beyond the classroom. Oxford: Macmillan.

Seferoğlu, G. (2005). Improving students' pronunciation through accent reduction software. British Journal of Educational Technology, 36(2), 303-316. http://dx.doi.org/10.1111/j.1467-8535.2005.00459.x

Sullivan, K., \& Czigler, P. (2002). Maximising the educational affordances of a technology supported learning environment for introductory undergraduate phonetics. British Journal of Educational Technology, 33(3), 333-343. http://dx.doi.org/10.1111/1467-8535.00268

Underhill, A. (2010). Pronunciation - the poor relation? Teaching English. BBC Council. Retrieved from $\mathrm{http} / / / \mathrm{www}$. teachingenglish.org.uk/articles/pronunciation-poor-relation

Vodopija-Krastanovic, I. (2012). NESTs versus non-NESTs: Rethinking English-language teacher identities. In J. I. Huttner, B. Mehlmauer-Larcher, S. Reichl, \& B. Schiftner (Eds.), Theory and practice in EFL teacher education: Bridge the gap. Ontario, Canada: Multilingual Matters.

Wei, M. (2006). A literature review on strategies for teaching pronunciation. (ERIC Document Reproduction Service No. ED 491566). Retrieved from http://www.eric.ed.gov/PDFS/ED491566.pdf

Yangın, E. C. (2015). A comparative analysis of practicum in English language teacher education: Turkey, Turkmenistan, Kyrgyzstan and Azerbaijan cases. The Anthropologist, 21(3), 461-473.

Zhang, F. (1998). Exploring computer-based browsing systems in the teaching of Chinese pronunciation. Language, Society and Culture. Retrieved from http://www.geocities.com/Athens/Troy/5618/PRONUNCIATION.HTML

\section{Copyrights}

Copyright for this article is retained by the author(s), with first publication rights granted to the journal.

This is an open-access article distributed under the terms and conditions of the Creative Commons Attribution license (http://creativecommons.org/licenses/by/3.0/). 